\title{
(อ) OPEN ACCESS \\ Fertility preservation for transgender children and young people in paediatric healthcare: a systematic review of ethical considerations
}

\author{
Chanelle Warton ๑ , Rosalind J McDougall
}

- Additional supplemental material is published online only. To view, please visit the journal online (http://dx.doi. org/10.1136/medethics-2021 107702).

Centre for Health Equity, Melbourne School of Population and Global Health, The University of Melbourne, Melbourne, Victoria, Australia

Correspondence to Dr Rosalind J McDougall, Centre of Health Equity, Melbourne School of Population and Global Health, The University of Melbourne, Melbourne, VIC 3010, Australia;

rmcdo@unimelb.edu.au

Received 29 June 2021 Accepted 3 October 2021
Check for updates

(c) Author(s) (or their employer(s)) 2022. Re-use permitted under CC BY-NC. No commercial re-use. See rights and permissions. Published by BMJ.

To cite: Warton $C$ McDougall RJ. J Med Ethics Epub ahead of print: [please include Day Month Year]. doi:10.1136/

medethics-2021-107702
ABSTRACT

Background While fertility preservation is recommended practice for paediatric oncology patients, it is increasingly being considered for transgender children and young people in paediatric care. This raises ethical issues for clinicians, particularly around consent and shared decision-making in this new area of healthcare.

Methods A systematic review of normative literature was conducted across four databases in June 2020 to capture ethical considerations related to fertility counselling and preservation in paediatric transgender healthcare. The text of included publications was analysed inductively, guided by the Qualitative Analysis Guide of Leuven.

Results Twenty-four publications were identified for inclusion. Four key ethical considerations emerged from this literature: access to fertility preservation, conscientious objection, decision-making capacity of children and young people, and shared decisionmaking.

Conclusion In the identified literature, there is consensus that transgender children and young people should not be refused access to fertility preservation services solely due to their gender identity, and that clinicians with conscientious objections to fertility preservation for this group have an obligation to refer on to willing providers. Factors that create ethical complexity in this area of paediatric care include the child's age, mental health, and parents' views.

\section{INTRODUCTION}

Fertility preservation and counselling are recommended medical practice for paediatric oncology populations. ${ }^{12}$ Fertility preservation strategies are increasingly considered in the context of paediatric transgender healthcare, as social acceptance of gender diversity and non-traditional family structures rises. ${ }^{3 \mathrm{i}}$ Transgender young people may choose to medically transition to improve the alignment of their gender identity and physical sex characteristics. ${ }^{4}$ Concerns around future fertility are salient for transgender young people as some medical transition pathways inhibit fertility. ${ }^{35}$

While research regarding the risks and benefits of fertility preservation specifically for transgender young people is limited, data from other

${ }^{\mathrm{i}}$ Transgender refers to individuals whose gender identities differ from their birth-assigned sex. ${ }^{6-8}$ Transgender is an umbrella term that includes numerous gender identities, including transgender male, transgender female, genderqueer and non-binary. ${ }^{9}$ populations indicate that infertility can negatively influence a person's psychosocial health. ${ }^{10}$ The World Professional Association for Transgender Health and clinical guidelines thus recommend fertility counselling prior to the commencement of medical transitioning for transgender children and young people. ${ }^{11-14}$

Counselling transgender young people and their families about fertility decision-making can be an ethically complex area for clinicians to navigate. There is a challenging mix of short-term and long-term risks and benefits to consider. Existing studies suggest that fertility concerns among transgender children and young people at presentation to a healthcare service may be neglected and the reduction of gender dysphoria prioritised. ${ }^{11-13 i}$ Transgender adolescents may prioritise medically transitioning to alleviate gender dysphoria over preserving their future fertility. ${ }^{12}{ }^{15}$ Decision-making related to paediatric transgender fertility preservation is complicated by the urgency to transition created by gender dysphoria, ${ }^{12}$ the lack of medical data on the permanency of some medical transition options, ${ }^{8}$ the experimental nature of some fertility preservation methods $^{816-18}$ and the potential for fertility preservation and counselling to exacerbate gender dysphoria. ${ }^{12} 1920$

Further, enacting the ethical ideal of shared decision-making is complex within fertility decisions in transgender paediatric care. Shared decisionmaking aims to appropriately support a child or young person's developing autonomy through active collaboration between the paediatric patient, their parents/guardians and healthcare professionals to determine a pathway of care. ${ }^{21}$ However, the capacity for autonomous decision-making varies greatly among children and young people, and health professionals must navigate a child's developing autonomy to enable competent young people to participate in decision-making, while ensuring children without capacity are involved in, but not responsible for, medical choices. ${ }^{22}$ In addition, shared decision-making presents challenges in paediatrics given the intertwined interests of family members, or situations in which parents' personal values differ from those of the young person. ${ }^{23}$

Fertility preservation and counselling for transgender children and young people are therefore ethically complex emerging areas of healthcare. To date, there has been no systematic review of

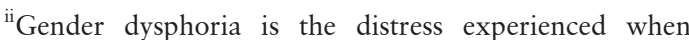
one's gender identity and physical characteristics are incongruent. $^{4}$ 
the ethical considerations relating to fertility preservation and counselling for transgender young people, and this paper sought to fill that gap. In identifying and synthesising the normative literature, we aimed to provide a resource for ethicists and clinicians to further develop ethical practice in this area. Our review addresses the following question: What are the ethical considerations relating to fertility counselling and preservation for transgender patients in paediatric healthcare? We first present an outline of the current fertility preservation options for transgender young people, followed by the methods used for the systematic review. We then describe the four key ethical considerations that emerged from this literature: access to fertility preservation, conscientious objection, decision-making capacity of children and young people, and shared decision-making.

In this paper, children and young people are defined as persons under 18 years of age or under the legal age of majority. ${ }^{2425}$ This population has been chosen to reflect the delineation between paediatric and adult healthcare services. Many health services recommend a patient transition from paediatric to adult settings at 16-18 years of age. ${ }^{26}{ }^{27}$ More transgender young people are presenting to paediatric settings for possible medical transition in regions where social acceptance of gender diversity is increasing, such as Australia. ${ }^{28}$ Paediatric settings were selected as the scope for this paper given the increasing need for fertility preservation and counselling in this age group.

\section{Fertility counselling for transgender children and young people}

The role of fertility counselling is to support patients to consider the impact of transitioning on their future fertility, and whether fertility preservation is a pathway that they would like to pursue. While the need for fertility counselling for transgender children and young people is acknowledged, there is little specification regarding its implementation in this context. ${ }^{3} 29$ Healthcare professionals may therefore vary in their knowledge, approach and comfort in communicating fertility preservation options to transgender young people. ${ }^{11} 123031$ For example, a national survey of 284 American endocrinologists found just 36\% of respondents felt adequately trained in fertility and $75 \%$ desired further guidance. ${ }^{32}$ Transgender children and young people are thus exposed to widely variant experiences, if any, of fertility counselling. ${ }^{12} 30$

Fertility counselling is appropriate prior to pubertal suppression and/or gender-affirming hormone therapy. Both pubertal suppression and gender-affirming hormone therapy are medical transition options available to transgender young people that may affect fertility. ${ }^{5}{ }^{30}$ The effects of puberty blockers are temporary and fertility returns when they are discontinued. ${ }^{33}$ Fertility may take 6 months to 2 years to resume. ${ }^{33}$ The permanency of infertility from gender-affirming hormone therapy is contested: recent studies report inconsistent fertility risks and outcomes. ${ }^{10}$ Hudson et al. propose that oestrogen hormone therapy can lead to irreversible azoospermia and that testosterone use may similarly impair fertility. ${ }^{5}$ Other studies note that, while there is potential for fertility impairment, the long-term implications of hormone therapy are unknown. ${ }^{812}$

Methods of available fertility preservation are dependent on a person's pubertal stage and birth-assigned sex (see table 1). For prepubertal children, all strategies aimed at fertility preservation are experimental or in development. ${ }^{816-18}$ Fertility preservation methods available exclusively to postpubertal individuals are increasingly routine practice among paediatric oncology populations. ${ }^{1730}$
Table 1 Methods of fertility preservation available to transgender children and young people ${ }^{1452-54}$

\begin{tabular}{lll}
\hline & \multicolumn{2}{l}{ Fertility preservation methods } \\
\cline { 2 - 3 } & Prepubertal & Postpubertal \\
\hline $\begin{array}{l}\text { Transgender females } \\
\text { (birth-assigned males) }\end{array}$ & $\begin{array}{l}\text { Testicular tissue } \\
\text { cryopreservation (TTC) }\end{array}$ & $\begin{array}{l}\text { Testicular tissue } \\
\text { cryopreservation (TTC) } \\
\text { Sperm cryopreservation }\end{array}$ \\
$\begin{array}{lll}\text { Transgender males } \\
\text { (birth-assigned females) }\end{array}$ & $\begin{array}{l}\text { Ovarian tissue } \\
\text { cryopreservation (OTC)* }\end{array}$ & $\begin{array}{l}\text { Ovarian tissue } \\
\text { cryopreservation (OTC) } \\
\text { Oocyte cryopreservation }\end{array}$ \\
\hline${ }^{*}$ Fertility preservation methods that are experimental or in development.
\end{tabular}

\section{METHODS}

To investigate the ethical considerations relating to fertility counselling and preservation for transgender patients in paediatric healthcare, a literature search was conducted in MEDLINE (Ovid), Scopus, PubMed and PsycInfo (Ovid) databases on 1 June 2020. Databases were chosen to provide broad coverage of social science, humanities and ethics publications in biomedical and health-related contexts.

The following search term was used in MEDLINE:

(transgender OR "trans" OR "gender variant" OR transsexual OR "gender diverse" OR "sex diverse" OR "non-binary" OR "gender identity disorder" OR "gender dysphoria") AND ("fertility counsel"* OR "fertility preserv" "OR "preservation of fertility") AND (ethic* OR normative OR moral*) AND (youth* OR adolescen* OR paediatric* OR pediatric* OR child* OR teen* OR young OR minor)

Identical or equivalent terms were searched in the remaining databases. Search terms were applied to titles, abstracts and keywords across all databases. Search terms were also applied to Medical Subject Headings (MeSH) fields in Ovid databases. Database searches generated 60 results, of which 32 were duplicates.

The full text of each publication was screened using the following inclusion criteria:

- The publication presents an ethical issue, argument or principle related to fertility counselling and/or preservation (see definitions in table 2). The ethical content could be a section or the entire publication. Such content must be explicitly identified as ethical by the publication's authors.

- The publication discusses fertility counselling and/or preservation in the context of transgender young people.

- The publication is in English.

Publications that exclusively discussed transgender adults and related interventions or had no discernible population age were excluded. Publications that addressed ethical considerations in the context of both transgender adults and children were included. No restrictions were placed on publication date given the contemporary nature of the topic. Similarly, no criterion was applied to publication type. An inclusive approach to publication type was chosen in recognition of the value of ethical discussion in a variety of publication types, such as letters. As is accepted practice for reviews of normative literature ${ }^{34}$ publications were deemed of sufficient quality for inclusion if they were obtained from peer-reviewed journals or book chapters from established academic publishers. ${ }^{35}$

Following the database searches, the reference list of each included publication was screened for relevant article titles. Article titles were deemed relevant if they addressed at least two aspects of the research question (e.g., fertility counselling 


\begin{tabular}{ll}
\hline Table 2 & Definitions of the types of ethical considerations \\
\hline $\begin{array}{l}\text { Ethical } \\
\text { consideration }\end{array}$ & Definition \\
\hline Ethical issue & $\begin{array}{l}\text { "Overarching category for actions or situations where } \\
\text { something has to be considered because of ethical reasons (or } \\
\text { principles and values), or is an object of ethical research" }\end{array}$ \\
Ethical argument & $\begin{array}{l}\text { "Normative justifications or refutations for moral claims or } \\
\text { action plans" }\end{array}$ \\
Ethical principle & $\begin{array}{l}\text { "Normative and theoretical concepts that summarise or describe } \\
\text { specific ideas about ethical behaviour or define a prerequisite } \\
\text { for ethical judgement" }\end{array}$ \\
\hline Quoted from Mertz et al. &
\end{tabular}

and transgender populations). Relevant publications were then subject to a full-text screening to determine inclusion or exclusion. This process was repeated until no new relevant titles were identified.

Database searches returned 60 results, of which 43 were duplicates or did not satisfy inclusion criteria. Reference list searches returned an additional 7 eligible publications. A total of 24 publications were thus included in this review (see online supplemental figure 1). One researcher initially identified the publications for inclusion. When it was unclear whether a publication should be included, this was resolved through discussion with the other researcher until consensus was reached for that publication. Data analysis and synthesis were guided by the Qualitative Analysis Guide of Leuven (QUAGOL). QUAGOL is an iterative, systematic method of data analysis. ${ }^{36}$ Initially, developed as a way of analysing qualitative interview data, it has been increasingly used in reviews of normative literature. ${ }^{3738}$ QUAGOL involves two parts, each consisting of five stages, where researchers manually draw themes from and subsequently code the literature. ${ }^{36}$

\section{RESULTS}

The 24 publications included in this review are presented in table 3. Ethics journals provided 5 of 24 publications (20.8\%). The majority of publications came from other contexts: clinical or legal journals, or social science journals and books. The novelty of this area of healthcare was reflected in the publication dates of the included literature, with 19 of 24 (79.2\%) publications dating from 2016 onwards. The focal demographics of the papers are presented in table 4. Ethical considerations in exclusively paediatric transgender populations were addressed in 9 of $24(37.5 \%)$ publications.

Four key ethical considerations emerged from the literature: access to fertility preservation, conscientious objection, decisional capacity of transgender children and young people and shared decision-making.

\section{Access to fertility preservation}

Arguments for and against the right to access fertility preservation are presented in the literature. However, there is consensus that fertility preservation should not be denied solely due to gender identity. ${ }^{5} 6811193039-42$ The Ethics Committee of the American Society for Reproductive Medicine affirm that "transgender identity/status by itself should not automatically bar a person from accessing fertility preservation" (p1114). ${ }^{41}$ Similarly, various authors argue for equity of access to fertility preservation services, specifically that transgender individuals deserve access to such services equal to that of others experiencing infertility. ${ }^{61941}$ While there is consensus that access to fertility preservation should not be denied on the basis of transgender identity, the literature provides three different justifications for this position, described below.

First, a transgender young person's right to access fertility preservation is justified by some authors on the basis of bodily autonomy or the child's right to an open future. ${ }^{8101219} 203143$ Clark and Virani note that "trans youth have the right to bodily autonomy, which includes decisions about... reproductive care" (p298). ${ }^{20}$ Quinn et al. highlight that "there is established support for fertility preservation for minors because it will ensure them an open future (that is, the possibility for biological children)" (p263). ${ }^{10}$ However, Clark and Virani argue that "it is not possible to preserve all open futures for all [transgender] youth. Therefore, caution must be exercised in privileging one future over another, as the harms caused by holding a particular future open may be significant" (p297)..$^{20}$

Second, possible harms to the transgender child or young person are considered as potential arguments against offering fertility preservation. ${ }^{5681119304142}$ While medical risks inherent to the fertility preservation process are noted, authors suggest these risks are negligible and could be addressed through the informed consent process. ${ }^{8} 193041$ Saraf and Nahata argue that while "the fertility preservation procedure itself... may potentially cause harm... Detailed discussions should occur with patients and families about potential risks vs benefits" (p318). ${ }^{30}$ Authors also identify the potential for social stigma and discrimination following fertility preservation as significant risks for transgender young people. ${ }^{19} 42$ De Wert et al. support that "risks [from fertility preservation] for applicants themselves are primarily social... transsexual parenthood may meet severe criticism and opposition" (p1861). ${ }^{19}$ However, Murphy argues that "given the vast array of parent-child relationships... it is unlikely that anyone could show that [transgender parenthood] ought to be prohibited because it poses harms to parents" (p314). ${ }^{11}$ Authors thus consider current and future risks associated with fertility preservation for this group, but overall suggest that these risks could be mitigated and/or do not justify denying access.

Third, the potential harm to future offspring resulting from transgender parenthood is acknowledged in the literature as a possible objection to enabling access to fertility preserva-

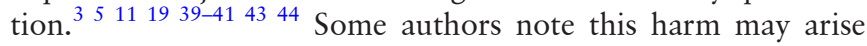
from discrimination towards the future offspring due to their parent's transgender identity. ${ }^{1939-4144}$ De Roo et al. confirm this, stating "that a child having a transgender parent may experience more transient and mild harassment than those who do not have a transgender parent" (p117). ${ }^{44}$ De Sutter additionally cites concerns around the transgender identity of the parent potentially influencing the gender identity of the future offspring. ${ }^{39}$ While Hudson et al. suggest the transgender identity of a parent is not inherently harmful, ${ }^{5}$ Murphy argues that, "in reproductive liberty, there is enough leeway for transgender parents to have children, even if there were some kind of undesirable outcome as a result" (p314). ${ }^{11}$ The literature does not support denying access to fertility preservation for transgender young people as a result of the potential harms to the transgender person themselves or their future offspring.

Alongside arguments for and against the right to access fertility preservation, the potential for fertility preservation to be financially prohibitive is noted in the literature. ${ }^{5} 810123031424546$ Hudson et al. state that cost may present a "significant [obstacle] to fertility preservation for transgender adolescents" (p89). Financial barriers to accessing fertility preservation are recognised as an issue of reproductive justice. ${ }^{12}$ Tishelman et al. 
Table 3 Publications included for analysis in this review

\begin{tabular}{|c|c|c|c|c|c|}
\hline \multicolumn{4}{|l|}{ Publication details } & \multicolumn{2}{|c|}{ Section for analysis } \\
\hline Publication title & Author & Year & Journal/book title & Page no. & Section title(s) \\
\hline $\begin{array}{l}\text { Words matter in the lives of transgender youth: Response to "Family } \\
\text { discordance regarding fertility preservation for a transgender teen: An } \\
\text { ethical case study" }\end{array}$ & Clark and Virani & 2019 & The Journal of Clinical Ethics & Whole document & - \\
\hline In response to "Words matter in the lives of transgender youth" & Quinn et al. & 2019 & The Journal of Clinical Ethics & Whole document & - \\
\hline $\begin{array}{l}\text { Ethical considerations in fertility preservation for transgender youth: A case } \\
\text { illustration }\end{array}$ & Chen and Simons & 2018 & $\begin{array}{l}\text { Clinical Practice in Pediatric } \\
\text { Psychology }\end{array}$ & Whole document & - \\
\hline Fertility counseling for transgender AYAs & Hudson et al. & 2018 & $\begin{array}{l}\text { Clinical Practice in Pediatric } \\
\text { Psychology }\end{array}$ & Whole document & - \\
\hline Fertility preservation for a transgender teenager & Nahata et al. & 2018 & Paediatrics & Whole document & - \\
\hline $\begin{array}{l}\text { Familial discordance regarding fertility preservation for a transgender teen: } \\
\text { An ethical case study }\end{array}$ & $\begin{array}{l}\text { Quinn, Sampson and } \\
\text { Campo-Engelstein }\end{array}$ & 2018 & The Journal of Clinical Ethics & Whole document & - \\
\hline Transgender reproductive choice and fertility preservation & Mitu & 2016 & AMA Journal of Ethics & Whole document & - \\
\hline $\begin{array}{l}\text { Access to fertility services by transgender persons: An Ethics } \\
\text { Committee opinion }\end{array}$ & $\begin{array}{l}\text { Ethics Committee of the } \\
\text { American Society for } \\
\text { Reproductive Medicine }\end{array}$ & 2015 & Fertility and Sterility & Whole document & - \\
\hline $\begin{array}{l}\text { ESHRE Task Force of Ethics and Law 23: Medically assisted reproduction in } \\
\text { singles, lesbian and gay couples, and transsexual people }\end{array}$ & De Wert et al. & 2014 & Human Reproduction & Whole document & - \\
\hline The ethics of fertility preservation in transgender body modifications & Murphy & 2012 & Bioethical Inquiry & Whole document & - \\
\hline $\begin{array}{l}\text { Gender reassignment and assisted reproduction: Present and future } \\
\text { reproductive options for transsexual people }\end{array}$ & De Sutter & 2001 & Human Reproduction & Whole document & - \\
\hline Adolescents and body modification for gender identity expression & Murphy & 2019 & Medical Law Review & Pg. 635-637 & $\begin{array}{l}\text { VI. The matter of fertility } \\
\text { preservation }\end{array}$ \\
\hline $\begin{array}{l}\text { Health care provider perceptions of fertility preservation barriers and } \\
\text { challenges with transgender patients and families: Qualitative responses to } \\
\text { an international survey }\end{array}$ & Tishelman et al. & 2019 & $\begin{array}{l}\text { Journal of Assisted } \\
\text { Reproduction and Genetics }\end{array}$ & Pg. 586 & Discussion \\
\hline $\begin{array}{l}\text { Towards trans reproductive justice: A qualitative analysis of views on } \\
\text { fertility preservation for Australian transgender and non-binary people }\end{array}$ & Riggs and Bartholomaeus & 2019 & Journal of Social Issues & Pg. 1-10, 18-22 & $\begin{array}{l}\text { Study 1; General discussion; } \\
\text { Conclusion }\end{array}$ \\
\hline $\begin{array}{l}\text { Advancing the practice of pediatric psychology with transgender youth: } \\
\text { State of the science, ongoing controversies, and future directions }\end{array}$ & Chen et al. & 2018 & $\begin{array}{l}\text { Clinical Practice in Pediatric } \\
\text { Psychology }\end{array}$ & Pg. 6-9 & Ongoing controversies \\
\hline Ethical issues in gender-affirming care for youth & Kimberly et al. & 2018 & Pediatrics & Pg. $4-7$ & $\begin{array}{l}\text { Autonomy and informed consent } \\
\text { and/or assent; Cost of care; } \\
\text { Conclusions }\end{array}$ \\
\hline $\begin{array}{l}\text { Chapter 5: Fertility treatment and preservation in transgender men and } \\
\text { women }\end{array}$ & Feldberg. & 2017 & $\begin{array}{l}\text { Principles of Gender-Specific } \\
\text { Medicine }\end{array}$ & Pg. 64-65 & $\begin{array}{l}5.6 \text { The ethical/legal status of } \\
\text { medically assisted reproduction } \\
\text { in transsexual people; } 5.7 \text { ART } \\
\text { treatment for transgender men } \\
\text { and women }\end{array}$ \\
\hline $\begin{array}{l}\text { Fertility counseling and preservation: Considerations for the pediatric } \\
\text { endocrinologist }\end{array}$ & Saraf and Nahata & 2017 & Translational Pediatrics & Pg. 318 & Ethical considerations \\
\hline $\begin{array}{l}\text { Fertility preservation for pediatric patients: Current state and future } \\
\text { possibilities }\end{array}$ & Johnson et al. & 2017 & Pediatric Urology & Pg. 191-192 & $\begin{array}{l}\text { Ethics of pediatric fertility } \\
\text { preservation; Financial } \\
\text { considerations; Summary and } \\
\text { conclusions; Appendix } 2\end{array}$ \\
\hline Preservation of fertility potential for gender and sex diverse individuals & Johnson and Finlayson & 2016 & Transgender Health & Pg. 42 & Ethics \\
\hline Fertility options in transgender people & De Roo et al. & 2016 & $\begin{array}{l}\text { International Review of } \\
\text { Psychiatry }\end{array}$ & Pg. 117 & $\begin{array}{l}\text { What is known about } \\
\text { transgender parenting and } \\
\text { children? }\end{array}$ \\
\hline $\begin{array}{l}\text { Transgender parenthood: Gamete preservation and utilization for } \\
\text { transgender people }\end{array}$ & De Sutter & 2016 & $\begin{array}{l}\text { Médecine de la Reproduction, } \\
\text { Gynécologie Endocrinologie }\end{array}$ & Pg. 110, 111, 113 & $\begin{array}{l}\text { Ethical arguments in favor of } \\
\text { fertility preservation; Future } \\
\text { possibilities }\end{array}$ \\
\hline $\begin{array}{l}\text { Proceedings of the working group session on fertility preservation for } \\
\text { individuals with gender and sex diversity }\end{array}$ & Finlayson et al. & 2016 & Transgender Health & Pg. 104-105 & Ethical concerns \\
\hline LGBT assisted reproduction: Current practice and future possibilities & Eyler, Pang and Clark & 2014 & LGBT Health & Pg. 155 & - \\
\hline
\end{tabular}

highlight the need for further guidance around counselling families without the financial resources for fertility preservation. ${ }^{47}$

\section{Conscientious objection}

The literature explores the issue of conscientious objection among health professionals in relation to fertility preservation for transgender young people. ${ }^{19}$ The American Medical Association states that physicians in public settings cannot object to treating patients on the basis of gender identity as this violates their greater duty to treat all individuals equally. ${ }^{41}$ Despite this obligation, authors note that the personal beliefs of physicians may still act as a barrier to fertility preservation services. ${ }^{41} 4245$
Mitu argues that "if clinicians believe that transpeople are unfit for parenting and should not be allowed to reproduce, this might prevent transpatients' access to relevant information about fertility preservation" (p1122). ${ }^{42}$

While some authors suggest that a physician's ethical entitlement to conscientiously object is outweighed by a greater duty of care, others suggest that conscientious objections should be respected. In contrast to the views of the American Medical Association, De Wert et al. argue that physicians' conscientious objections should be respected and that these physicians are obligated to refer patients to another clinic known not to hold 


\begin{tabular}{ll}
\hline Table $4 \quad$ Focal demographic of included publications & \\
\hline Demographic & $\begin{array}{l}\text { No. } \\
(\mathbf{n}=\mathbf{2 4})\end{array}$ \\
\hline Age & 14 \\
\hline Paediatric & 10 \\
\hline Paediatric and adult & \\
\hline Population & 17 \\
\hline Transgender only & 2 \\
\hline Transgender and DSD & 2 \\
\hline Transgender, DSD, oncology and immunosuppressed & 1 \\
\hline Transgender and gender non-conforming & 1 \\
\hline Transgender, lesbian, gay and bisexual & 1 \\
\hline Transgender, lesbian, gay and single parents &
\end{tabular}

DSD, disorder/difference of sex development.

such an objection. ${ }^{19}$ The ethical obligation to refer patients to alternate clinics is also recognised when providers lack sufficient resources to provide age-appropriate fertility preservation and/ or counselling. ${ }^{51}$ These resources include training related to the provision of fertility services to young transgender people. ${ }^{541}$ Inadequate training is associated with provider discomfort and embarrassment which obstructs access to appropriate healthcare. $^{51241}$

\section{Decision-making capacity of children and young people}

In the included literature, age is highlighted as influencing the capacity of transgender young people to make fertility decisions. Many authors consider the circumstances in which a young person is able to consent or assent to medical procedures, including fertility preservation. ${ }^{3512151931464849}$ Some authors also argue that fertility preservation decisions may be difficult for young people given their lack of concern about future fertility. ${ }^{12313942}$ Chen and Simons write that "transgender adolescents must consider desires for biological parenthood during a period in which thinking about family formation is developmentally non-normative" (p95). ${ }^{12}$ While determining decisional capacity can be complex, Nahata et al. note the discordance between allowing young people to make decisions about their transition but not participate in fertility-related choices, stating that "it would be hypocritical to deny [a transgender young person's] decision to refuse [fertility preservation]" (p4). ${ }^{31}$

The literature highlights the potential effect of psychological comorbidities on a young person's decisional capacity. ${ }^{5} 1231$ Some authors argue that the urgency to transition created by gender dysphoria can compromise a young person's decisional capacity. ${ }^{12} 1531$ Several authors argue that transgender young people can be additionally deterred by the distressing and/or invasive nature of the preservation itself. ${ }^{35812} 2031$ Hudson et al. acknowledge that "the focus on parts and functions of the body typically associated with motherhood can heighten feelings of dysphoria" during fertility preservation for transgender men (p89). ${ }^{5}$ Authors also argue that other psychological or cognitive comorbidities can influence an individual's ability to make fertility-related decisions. ${ }^{512} 3031$

\section{Roles in shared decision-making}

Many authors acknowledge the ethical challenges that arise for providers from shared decision-making with the transgender young person's parents, particularly when guardians and young people disagree. ${ }^{3510193031454648}$ Johnson et al. articulate a key question facing clinicians: given "patient wishes may be at odds with parental wishes-how to proceed?" (p192). ${ }^{8}$ The literature identifies the involvement of parents in decision-making as particularly ethically challenging given the young person may be dependent for care and financial resources. ${ }^{10} 1249$ Some authors also acknowledge ethical challenges arising from decisional conflict between parents. ${ }^{81048}$ Kimberley et al. argue that "dual parent consent may be unnecessarily prohibitive for adolescents who come from households with only 1 parent who is actively involved in the child's life or in situations in which there may be interparental conflict" (p5). ${ }^{46}$ Authors note that navigating shared decision-making may be particularly complex for providers when parents refuse fertility preservation desired by the young person or are generally unsupportive of their child's gender transition. ${ }^{510}$

Given the significant involvement of parents in the fertility decision-making process, some authors argue that ownership of preserved tissue should be considered and established prior to fertility interventions. ${ }^{804648}$ Eyler et al. raise the question "can the parents use the gametes without the permission of their children, either before or after they reach the age of majority?" (p155). ${ }^{4 \text { iii }}$ The majority of ethical challenges identified by the literature related to the involvement of parents in shared decision-making.

Broader ethical challenges related to shared decision-making in fertility preservation for transgender young people are also raised. Authors argued that the complexities and costs associated with future methods of achieving parenthood, such as the use of assisted reproductive technologies (ART), are an influential part of shared fertility-related decisions. ${ }^{5} 10123142$ Some authors suggest that a young person's value of genetic filial relations could influence their selected method of future parenthood. ${ }^{5101131}$ Hudson et al. argue that physicians "should also help [transgender youth] to explore how much [they value] the idea of a genetic relationship between [themselves] and any potential offspring as that is a salient difference between [ART and adoption]" (p89). ${ }^{5}$ For transgender young people who desire genetic parenthood, the literature argues that barriers to the use of preserved tissue should be discussed. ${ }^{811} 121943$ Johnson et al. suggest that "families should... be informed of the future costs of reproductive medicine services" (p192), ${ }^{8}$ while Mitu notes that "the social... stigma and discrimination against gender and sexual minorities" is a challenge when accessing ART (p1122). ${ }^{42}$ Alongside exploration of future ART use, the lack of medical data related to the outcomes of tissue cryopreservation is identified as complicating shared fertility-related decisions. ${ }^{815} 20334041454648$ Quinn et al. state that "the ambiguity of available medical information can lead to anxiety and distress and complicate decision-making" (p299). ${ }^{33}$ Experimental methods of fertility preservation may be "the only chance to preserve the possibility of biological parenthood" for transgender children (p192), ${ }^{8}$ while simultaneously exposing them to "surgical risk and storing gonadal tissue without the guarantee of future fertility" (p42). ${ }^{3}$

\section{LIMITATIONS}

This paper applied search terms to abstracts, titles, MeSH fields (in relevant databases) and keywords. Publications that included ethical considerations in the body of their work but did not explicitly note this in one of the above fields may thus not have been captured.

iii It is worth noting that legal precedents around parental usage vary 
Publications were required to explicitly identify their consideration of ethical issues to be included. Considerations that could be understood as ethical but were not explicitly identified as such were excluded. This approach to inclusion was chosen to ensure the accurate representation of arguments from the literature and reduce reliance on researcher subjectivity.

The databases used in this paper aimed to capture a variety of social science, humanities and medical publications. MEDLINE (Ovid) and PsycInfo (Ovid) were used but did not return any unique results. MEDLINE (Ovid) is indexed in PubMed and was thus subsequently found not to be relevant. The lack of unique results returned from PsycInfo (Ovid) may reflect the emerging nature of fertility preservation for transgender young people and could prove useful upon further development of the area. While subsequent searches on our topic in Philosopher's Index, PhilPapers and BELIT did not generate additional results, these databases may be appropriate for consideration by others embarking on systematic reviews in bioethics.

\section{CONCLUSION}

There is an emerging body of normative literature exploring the ethical challenges involved in fertility preservation and counselling for transgender children and young people in paediatric care. This literature coalesces around four ethical considerations: access to fertility preservation by this population, physicians' conscientious objection, the decisional capacity of transgender young people, and complexities surrounding shared decision-making particularly in relation to parents. In the included literature, there is consensus that transgender children and young people should not be refused access to fertility preservation services solely due to their gender identity, and that clinicians with conscientious objections to fertility preservation for this group have an obligation to refer on to willing providers. The ethical complexity of fertility decision-making in paediatric gender healthcare depends on the child's age, mental health, and parents' views. The unique potential for social opposition to transgender identities and related treatment from parents or healthcare providers may also limit access to fertility preservation by paediatric patients.

This systematic review has explicitly identified and synthesised relevant existing ethical considerations, with the aim of informing the practice of clinicians and clinical ethicists in this emerging area of healthcare. It is important to note that paediatric transgender patients' access to fertility preservation and counselling is limited to countries where there are adequate financial resources and social acceptance. Normative literature currently available in relation to this practice thus reflects the ethical considerations specific to these geographical and social contexts. If the availability of fertility preservation and counselling for paediatric transgender patients expands, future research should aim to capture possible variations in ethical considerations that arise due to cultural context. Further research comparing the ethical considerations arising from fertility preservation and counselling for transgender young people and other paediatric populations where fertility preservation is more established, such as paediatric oncology populations, would be useful. Empirical bioethics research to understand the experiences of clinicians, parents and transgender young people in relation to the ethical aspects of fertility-related decision-making would also be highly valuable.

\section{Twitter Rosalind J McDougall @ethicsros}

Contributors RJM conceptualised the study. Both authors designed the search. $\mathrm{CW}$ led the data collection and analysis, and wrote the first draft of the manuscript.
RJM made substantive revisions to the paper. The study was completed as CW's research project in the Master of Public Health, supervised by RJM. Both authors finalised and approved the text.

Funding The authors have not declared a specific grant for this research from any funding agency in the public, commercial or not-for-profit sectors.

Competing interests None declared.

Patient consent for publication Not applicable.

Provenance and peer review Not commissioned; externally peer reviewed.

Data availability statement No data are available.

Supplemental material This content has been supplied by the author(s). It has not been vetted by BMJ Publishing Group Limited (BMJ) and may not have been peer-reviewed. Any opinions or recommendations discussed are solely those of the author(s) and are not endorsed by BMJ. BMJ disclaims all liability and responsibility arising from any reliance placed on the content. Where the content includes any translated material, BMJ does not warrant the accuracy and reliability of the translations (including but not limited to local regulations, clinical guidelines, terminology, drug names and drug dosages), and is not responsible for any error and/or omissions arising from translation and adaptation or otherwise.

Open access This is an open access article distributed in accordance with the Creative Commons Attribution Non Commercial (CC BY-NC 4.0) license, which permits others to distribute, remix, adapt, build upon this work non-commercially, and license their derivative works on different terms, provided the original work is properly cited, appropriate credit is given, any changes made indicated, and the use is non-commercial. See: http://creativecommons.org/licenses/by-nc/4.0/.

\section{ORCID iDs}

Chanelle Warton http://orcid.org/0000-0002-7838-4636

Rosalind J McDougall http://orcid.org/0000-0002-3809-2575

\section{REFERENCES}

1 Oktay K, Harvey BE, Partridge AH, et al. Fertility preservation in patients with cancer: ASCO clinical practice guideline update. J Clin Oncol 2018;36(19):1994-2001.

2 Yasmin E, Balachandren N, Davies MC, et al. Fertility preservation for medical reasons in girls and women: British fertility Society policy and practice guideline. Hum Fertil 2018;21(1):3-26.

3 Johnson EK, Finlayson C. Preservation of fertility potential for gender and sex diverse individuals. Transgend Health 2016;1(1):41-4.

4 Telfer MM, Tollit MA, Pace CC, et al. Australian standards of care and treatment guidelines for transgender and gender diverse children and adolescents. Med J Aust 2018;209(3):132-6.

5 Hudson J, Nahata L, Dietz E, et al. Fertility counseling for transgender AYAs. Clin Pract Pediatr Psychol 2018;6(1):84-92.

6 Feldberg D. Fertility Treatment and Preservation in Transgender Men and Women. In: Legato M, ed. Principles of gender-specific medicine: gender in the genomic era. London: Academic Press, 2017: 61-7.

7 Lai TC, McDougall R, Feldman D, et al. Fertility counseling for transgender adolescents: a review. J Adolesc Health 2020;66(6):658-65.

8 Johnson EK, Finlayson C, Rowell EE, et al. Fertility preservation for pediatric patients: current state and future possibilities. J Urol 2017;198(1):186-94.

9 Strauss P, Cook A, Winter S. Trans pathways: the mental health experiences and care pathways of trans young people. Summary of results. Telethon Kids Institute, 2017. Available: www.telethonkids.org.au/globalassets/media/documents/brain-behaviour/ trans-pathwayreport-web.pdf [Accessed June 2020].

10 Quinn GP, Sampson A, Campo-Englestein L. Familial discordance regarding fertility preservation for a transgender teen: an ethical case study. J Clin Ethics 2018:29(4):261-5.

11 Murphy TF. The ethics of fertility preservation in transgender body modifications. J Bioeth Inq 2012;9(3):311-6.

12 Chen D, Simons L. Ethical considerations in fertility preservation for transgender youth: a case illustration. Clin Pract Pediatr Psychol 2018;6(1):93-100.

13 The World Professional Association for Transgender Health. Standards of care for the health of transsexual, transgender, and Gender-Nonconforming people, 2012. Available: www.wpath.org/media/cms/Documents/SOC $\% 20 \mathrm{v} 7 /$ Standards $\% 20$ of $\%$ 20Care_V7\%20Full\%20Book_English.pdf [Accessed June 2020].

14 The Royal Children's Hospital Melbourne. The Royal Children's Hospital fertility preservation principles of care and guidance, 2019. Available: www.rch.org.au/ uploadedFiles/Main/Content/fertility/Fertility-preservation-guidance.pdf [Accessed July 2020].

15 Chen D, Edwards-Leeper L, Stancin T, et al. Advancing the practice of pediatric psychology with transgender youth: state of the science, ongoing controversies, and future directions. Clin Pract Pediatr Psychol 2018;6(1):73-83.

16 Campo-Engelstein L, Chen D, Baratz AB, et al. Fertility preservation for a teenager with differences (disorders) of sex development: an ethics case study. J Clin Ethics 2019;30(2):143-53. 
17 Cancer Council NSW. Preserving fertility in children and adolescents, 2020. Available: www.cancercouncil.com.au/cancer-information/managing-cancer-side-effects/fertilityand-cancer/fertility-options-for-children-and-adolescents/ [Accessed July 2020].

18 Leonel ECR, Lucci CM, Amorim CA. Cryopreservation of human ovarian tissue: a review. Transfus Med Hemother 2019:46:1-9.

19 De Wert G, Dondorp W, Shenfield F, et al. ESHRE Task force on ethics and law 23: medically assisted reproduction in singles, lesbian and gay couples, and transsexual peoplet. Hum Reprod 2014;29(9):1859-65.

20 Clark BA, Virani A. Letter: Words Matter in the Lives of Transgender Youth: Response to "Family Discordance Regarding Fertility Preservation for a Transgender Teen: An Ethical Case Study". J Clin Ethics 2019;30(3):297-9.

21 Park ES, Cho IY. Shared decision-making in the paediatric field: a literature review and concept analysis. Scand J Caring Sci 2018:32(2):478-89.

22 Hein IM, De Vries MC, Troost PW, et al. Informed consent instead of assent is appropriate in children from the age of twelve: policy implications of new findings on children's competence to consent to clinical research. BMC Med Ethics 2015;16(1):76.

23 Wyatt KD, List B, Brinkman WB, et al. Shared decision making in pediatrics: a systematic review and meta-analysis. Acad Pediatr 2015;15(6):573-83.

24 World Health Organization. Definition of key terms HIVIAIDS, 2013. Available: www. who.int/hiv/pub/guidelines/arv2013/intro/keyterms/en/ [Accessed Aug 2020].

25 United Nations General Assembly. Convention on the Rights of the Child. United Nations Human Rights Office of the High Commissioner, 1989. Available: www.ohchr. org/en/professionalinterest/pages/crc.aspx [Accessed Jun 2020].

26 Great Ormond Street Hospital for Children. Transition to adult services, 2020. Available: www.gosh.nhs.uk/your-hospital-visit/transition-adult-services [Accessed Jun 2020].

27 The Royal Children's Hospital Melbourne. Transition to adult health services. Kids Health Info, 2007. Available: www.rch.org.au/kidsinfo/fact_sheets/Transition_to_ adult_health_services/ [Accessed Jun 2020].

28 The Royal Children's Hospital Melbourne. The gender service background, funding and program logic. Available: https://www.rch.org.au/adolescent-medicine/gender-service/ The_Gender_Service_background,_funding_and_program_logic/ [Accessed Sep 2021].

29 Cheng PJ, Pastuszak AW, Myers JB, et al. Fertility concerns of the transgender patient. Trans/ Androl Urol 2019;8(3):209-18.

30 Saraf AJ, Nahata L. Fertility counseling and preservation: considerations for the pediatric endocrinologist. Trans/ Pediatr 2017;6(4):313-22.

31 Nahata L, Campo-Engelstein LT, Tishelman A, et al. Fertility preservation for a transgender teenager. Pediatrics 2018;142(3). doi:10.1542/peds.2017-3142. [Epub ahead of print: 0208 2018].

32 Nahata L, Ziniel SI, Garvey KC, et al. Fertility and sexual function: a gap in training in pediatric endocrinology. J Pediatr Endocrinol Metab 2017;30(1):3-10.

33 Quinn GP, Sampson A, Campo-Engelstein L, et al. Letter: In Response to "Words Matter in the Lives of Transgender Youth". J Clin Ethics 2019:30(3):299-300.

34 McDougall RJ, Notini L. Overriding parents' medical decisions for their children: a systematic review of normative literature. J Med Ethics 2014;40(7):448-52.

35 McDougall R. Systematic reviews in bioethics: types, challenges, and value. J Med Philos 2014;39(1):89-97.
36 Dierckx de Casterlé B, Gastmans C, Bryon E, et al. QUAGOL: a guide for qualitative data analysis. Int J Nurs Stud 2012:49(3):360-71.

37 Wright DK, Gastmans C, Vandyk A, et al. Moral identity and palliative sedation: a systematic review of normative nursing literature. Nurs Ethics 2020:27(3):868-86.

38 Rodrigues P, Crokaert J, Gastmans C. Palliative sedation for existential suffering: a systematic review of argument-based ethics literature. J Pain Symptom Manage 2018:55(6):1577-90

39 De Sutter P. Transgender parenthood: gamete preservation and utilization for transgender people. Med Ther Med Reprod Gynecol Endocrinol 2016;18:109-15.

40 De Sutter P. Gender reassignment and assisted reproduction: present and future reproductive options for transsexual people. Hum Reprod 2001;16(4):612-4.

41 Ethics Committee of the American Society for Reproductive Medicine. Access to fertility services by transgender persons: an ethics Committee opinion. Fertil Steril 2015; 104(5):1111-5.

42 Mitu K. Transgender reproductive choice and fertility preservation. AMA J Ethics 2016;18(11):1119-25.

43 Murphy TF. Adolescents and body modification for gender identity expression. Med Law Rev 2019;27(4):623-39.

44 De Roo C, Tilleman K, T'Sjoen G, et al. Fertility options in transgender people. Int Rev Psychiatry 2016;28(1):112-9.

45 Riggs DW, Bartholomaeus C. Toward trans reproductive justice: a qualitative analysis of views on fertility preservation for Australian transgender and Non-binary people. J Soc Issues 2020;76(2):314-37.

46 Kimberly LL, Folkers KM, Friesen P, et al. Ethical issues in gender-affirming care for youth. Pediatrics 2018;142(6). doi:10.1542/peds.2018-1537. [Epub ahead of print: 0611 2018].

47 Tishelman AC, Sutter ME, Chen D, et al. Health care provider perceptions of fertility preservation barriers and challenges with transgender patients and families: qualitative responses to an international survey. J Assist Reprod Genet 2019;36(3):579-88.

48 Finlayson C, Johnson EK, Chen D, et al. Proceedings of the Working group session on fertility preservation for individuals with gender and sex diversity. Transgend Health 2016;1(1):99-107.

49 Eyler AE, Pang SC, Clark A. LGBT assisted reproduction: current practice and future possibilities. LGBT Health 2014;1(3):151-6.

50 Stegmann BJ. Unique ethical and legal implications of fertility preservation research in the pediatric population. Fertil Steril 2010;93(4):1037-9.

51 Peart N. Life beyond death: regulating posthumous reproduction in New Zealand. VUWLR 2015;46(3):725-54.

52 Sterling J, Garcia MM. Fertility preservation options for transgender individuals. Trans/ Androl Urol 2020;9(Suppl 2):S215-26.

53 Mattawanon N, Spencer JB. Schirmer dA 3rd, Tangpricha V. fertility preservation options in transgender people: a review. Rev Endocr Metab Disord 2018;19(3):231-42.

54 Baram S, Myers SA, Yee S, et al. Fertility preservation for transgender adolescents and young adults: a systematic review. Hum Reprod Update 2019;25(6):694-716.

55 Mertz M, Strech D, Kahrass H. What methods do reviews of normative ethics literature use for search, selection, analysis, and synthesis? in-depth results from a systematic review of reviews. Syst Rev 2017;6(1):261. 